\title{
HAMBATAN KURATOR DALAM MENYELESAIKAN PIUTANG KOPERASI YANG DIPUTUS PAILIT
}

\author{
Nindita WidiAfreeportamara \\ E-mail: ninditawidi@student.uns.ac.id \\ Mahasiswa S1 Program Studi Ilmu Hukum, Fakultas Hukum, Universitas Sebelas Maret \\ Surakarta \\ Pujiyono \\ E-mail:pujifhuns@gmail.com \\ Dosen Fakultas Hukum, Universitas Sebelas Maret Surakarta
}

\begin{abstract}
This article discusses the challenges posed by curators in handling bankrupt assets and their solutions. This study uses normative or doctrinal legal research methods that act prescriptively or applied. This study uses sources of primary and secondary legal materials. The analysis technique used is the syllogism method that uses deductive thinking patterns. Based on the results of this study it can be concluded. Curators when settling receivables of cooperatives that are decided bankrupt experience obstacles, namely in terms of regulations in the form of a lack of legal protection for curators and collisions between Law Number 37 of 2004 concerning bankruptcy and postponement of debt repayment obligations Article 9 and Article 16. The Cooperative Management still recognizes cooperative assets and the existence of irresponsible Managers. In the case of the amount of money spent for the Cooperative in a state of loss and unable to pay its debts. Curators have difficulty determining Creditors and there are Fictitious Creditors, the last to approve the funds because they ask the Cooperative that is terminated requires not small amounts of funds
\end{abstract}

Keywords: obstacle; bankruptcy; cooperative; curators

\begin{abstract}
Abstrak
Artikel ini bertujuan untuk mengetahui hambatan-hambatan yang dihadapi oleh kurator dalam mengurus harta pailit beserta solusinya. Penelitian ini menggunakan metode penelitian hukum normatif atau doktrinal yang bersifat preskriptif atau terapan. Penelitian ini menggunakan sumber bahan hukum primer dan sekunder. Teknik analisis yang digunakan yaitu dengan metode silogisme yang menggunakan pola berpikir deduktif. Berdasarkan hasil penelitian ini dapat disimpulkan. Kurator saat menyelesaikan piutang koperasi yang diputus pailit mengalami hambatan-hambatan yaitu dalam hal regulasi berupa kurangnya perlindungan hukum terhadap kurator dan benturan antara Pasal 9 dan Pasal 16 Undang-undang Nomor 37 Tahun 2004 tentang kepailitan dan penundaan kewajiban pembayaran utang. Pengurus Koperasi masih menguasai harta koperasi dan adanya Pengurus yang tidak bertanggung jawab. Dalam hal Jumlah harta yaitu apabila Koperasi dalam keadaan merugi dan tidak dapat membayar utang-utangnya. Kurator kesulitan menentukan Kreditor dan terdapat Kreditur Fiktif ,yang terakhir Ketersediaan dana karena penyelesaian suatu Koperasi yang diputus membutuhkan dana yang tidak sedikit.
\end{abstract}

Kata kunci: hambatan; kepailitan; koperasi; kurator 


\section{A. Pendahuluan}

Pada proses kepailitan maka setelah jatuhnya putusan kepailitan ada dua organ yang sangat berperan aktif dalam pelaksanaannya, yaitu hakim pengawas yang bertugas mengawasi pengurusan dan pemberesan, kemudian kurator yang bertugas melakukan pengurusan dan pemberesan harta pailit. Hal ini dikarenakan setelah dinyatakan pailit, debitor pailit menurut hukum sudah tidak memiliki kemampuan untuk mengelola harta kekayaannya, sehingga ditunjuklah seorang kurator untuk mengelola, mengurus dan melakukan pemberesan terhadap harta pailit tersebut.

Salah satu bagian terpenting dalam penyelesaian perkara kepailitan adalah kurator. Kurator dalam menjalankan tugas harus memahami bahwa tugasnya tidak sekedar menyelamatkan harta pailit yang berhasil dikumpulkannya untuk kemudian dibagikan kepada para kreditor tapi sedapat mungkin bisa meningkatkan nilai harta pailit debitor. Lebih jauh lagi kurator juga dituntut untuk memiliki integritas yang berpedoman pada kebenaran dan keadilan serta keharusan untuk menaati standar profesi dan etika. Keharusan ini bertujuan menghindari adanya benturan kepentingan dengan debitor ataupun kreditor (Imran Nating, 2004:192).

Kurator sejak ditunjuk berdasarkan putusan pengadilan wajib mengamankan budel pailit sehingga nantinya dapat dilaksanakan pemberesan dan pelunasan terhadap tagihan kreditor yang telah diakui dan dicocokkan piutangnya.

Penyelesaian pemberesan atas harta pailit merupakan salah satu acara dalam kepailitan yang melibatkan kurator untuk melakukan pengurusan dan atau pemberesan harta pailit. Kurator mulai bertugas sejak Kepailitan diputuskan, karena debitor tidak berhak lagi untuk melakukan pengurusan atas harta kekayaannya. Kurator merupakan satu-satunya pihak yang akan menangani seluruh kegiatan pengurusan dan pemberesan harta pailit.

Pelaksanaan tugas kurator harus dilakukan oleh seorang yang profesional dan mengerti segala seluk beluk serta mekanisme yang diatur dalam undang-undang. Kurator dalam menjalankan tugas kepengurusannya terhadap harta pailit, bertanggung jawab atas kesalahan atau kelalaiannya yang menyebabkan kerugian terhadap harta pailit dan segala tindakannya yang berkaitan dengan pengurusan dan pemberesan harta pailit, kemudian secara berkala kurator harus menyampaikan laporan kepada hakim pengawas.

Namun dalam pelaksanaan penyelesaian piutang koperasi,kurator mengalami hambatan. Banyak masalah yang menghambat kinerja kurator,. disini penulis menganalisis bagaimana solusi atas hambatan-hambatan kurator dalam menyelesaikan piutang.

\section{B. Metode Penelitian}

Jenis penelitian yang digunakan dalam penulisan hukum ini adalah penelitian hukum normatif atau biasa dikenal dengan hukum doktrinal, yaitu penelitian yang dilakukan dengan cara meneliti bahan pustaka yang terdiri dari bahan hukum primer, bahan hukum sekunder dan bahan hukum tersier. Menurut Peter Mahmud Marzuki, semua penelitian yang berkaitan dengan (legal research) adalah selalu normatif. Jika tipe penelitian ini harus dinyatakan dala bentuk tulisan cukup dikemukakan bahwa penelitian ini adalah penelitian hukum. Dengan adanya pernyataan demikian maka sudah jelas bahwa penelitian tersebut bersifat normatif. Hanya saja pendekatan dan bahan-bahan hukum yang digunakan harus dikemukakan (Peter Mahmud Marzuki, 2014: 55-56). 
Nindita Widi Afreeportamara, Pujiyono. Hambatan kurator dalam menyelesaikan ...

Dalam Penelitian hukum ini, penulis menggunakan pendekatan perundang undangan (statue approach) yaitu pendekatan dengan mencari peraturan perundang undangan yang terkait. Karena di dalam penelitian hukum ini, penulisakan memecahkan permasalahan hukum berdasarkan dengan peraturan perundang-undangan yang berlaku.

Teknik analisis data menggunakan menggunakan teknik analisis data kualitatif dengan menggunakan, mengelompokkan, dan menyeleksi data yang diperoleh dari penelitian lapangan, kemudian dihubungkan dengan teori-teori, asas-asas, dan kaidah-kaidah hukum yang diperoleh dari studi kepustakaan.

\section{Hasil Penelitian dan Pembahasan}

Peranan kurator yang penting dalam penyelesaian utang piutang dapat mengalami beberapa hambatan. Hambatan tersebut dapat menyebabkan proses pengurusan dan pemberesan yang dilakukan menjadi semakin memakan waktu dan kerja kurator menjadi tidak efektif dan efisien. Hambatan tersebut terbagi dalam hal :

\section{Regulasi}

Dalam menjalankan tugasnya kurator mengalami beberapa hambatan dalam hal regulasi, hambatan tersebut berupa:

a) Kurangnya Perlindungan Hukum terhadap Kurator

Seorang kurator dalam menjalankan tugasnya tidaklah boleh melakukan tindakan sewenang-wenang yang melewati koridor hukumnya dan perlu memperhatikan beberapa hal yakni seperti apakah ia memiliki wewenang untuk melakukan tindakan tersebut, kemudian apakah tindakannya sesuai dengan keaadan maupun kondisi yang tepat dengan memperhatikan faktor ekonomi dan bisnis, apakah dalam menjalankan tindakan tersebut diperlukan persetujuan atau keikutsertaan dari pihak-pihak tertentu, seperti hakim pengawas, pengadilan niaga, debitor, panitia kreditor dan sebagainya (Ida Bagus Adi Wiradharma, 2018: 6).

Tugas kurator diatur pada Pasal 69 ayat (1) Undang-undang Nomor 37 Tahun 2004 tentang Kepailitan dan Penundaan Kewajiban Pembayaran Utang yang menyebutkan bahwa "Tugas kurator adalah melakukan pengurusan dan/atau pemberesan harta pailit". Ketika menjalankan tugasnya Kurator memiliki begitu banyak hal yang harus dikerjakan dan tanggung jawab yang juga begitu besar, hal ini tentunya dapat menjadi semakin rumit karena tidak jarang seorang kurator akan menghadapi beberapa hambatan yang dilakukan oleh pihak-pihak yang tidak menginginkan adanya kepailitan. Hambatan-hambatan tersebut dapat berupa sikap non kooperatif dari kreditor maupun debitor pailit, kemudian dapat berupa kekerasan fisik maupun psikologis yang dapat mempengaruhi indepedensi dari seorang kurator, dimana kurator akan menjadi berat ke salah satu pihak dalam menjalankan tugasnya, dimana seharusnya dalam menjalankan tugasnya. Melihat hal tersebut perlu suatu bentuk nyata perlindungan hukum bagi para kurator, baik dengan adanya suatu aturan khusus tentang perlindungan terhadap kurator yang sedang menjalankan tugasnya dan juga peran aktif aparat hukum untuk memberikan perlindungan bagi para kurator.

Namun bila dikaitkan dengan Undang-Undang Nomor 37 Tahun 2004 tentang Kepailitan dan Penundaan Kewajiban Pembayaran Utang yang mengatur mengenai 
keberadaan kurator dan tugas-tugas kurator, undang-undang ini belumlah memuat secara implisit mengenai perlindungan hukum bagi kurator dalam menjalankan tugas pengurusan maupun pemberesan harta pailit. Hal ini kurator dalam menjalankan tugasnya dapat menimbulkan ketidakpastian hukum.

Pelaksanaan tugas kurator yang kemudian mengalami hambatan-hambatan tentunya akan memberatkan kurator secara pribadi, sehingga perlindungan hukum terhadap kurator dalam menjalankan tugas pengurusan atau pemberesan harta pailit sangatlah diperlukan. Pasal 50 KUH Pidana menyatakan sebagai berikut : "Barang siapa melakukan perbuatan untuk melaksanakan ketentuan Undang-Undang, tidak di pidana", pasal tersebut memuat ketentuan yang memberikan perlindungan hukum terhadap tindakan yang dilakukan kurator yakni terhadap siapapun yang melakukan perbuatan guna melaksanakan ketentuan dari peraturan perundang-undangan, tidak akan dipidana. Pasal tersebut tentunya memberikan perlindungan hukum kepada kurator dari segala hambatan yang mungkin dilakukan oleh debitur pailit maupun kreditur sepanjang tindakan yang dilakukan kurator merupakan tindakan yang dijalankan berdasarkan ketentuan dari undang-undang.

b) Undang-undang Nomor 37 Tahun 2004 tidak jelas mengatur kapan legalitas diberikan kepada kurator untuk melaksanakan tugasnya sehingga terjadi benturan antara Pasal 9 dan Pasal 16 Undang-undang Nomor 37 Tahun 2004.

Pasal 15 ayat (1) Undang-Undang Nomor 37 Tahun 2004 tentang Kepailitan dan Penundaan Kewajiban Pembayaran Utang menentukan bahwa dalam putusan pernyataan pailit harus diangkat kurator dan hakim pengawas yang ditunjuk dari hakim pengadilan. Pasal 16 Undang-undang Nomor 37 Undang-Undang Nomor 37 Tahun 2004 tentang Kepailitan dan Penundaan Kewajiban Pembayaran Utang, kurator menyatakan bahwa berwenang melaksanakan tugas pengurusan dan/atau pemberesan atas harta pailit sejak tanggal putusan pailit diucapkan meskipun terhadap putusan tersebut diajukan kasasi atau peninjauan kembali kemudian apabila pailit dibatalkan akibat adanya kasasi atau peninjauan kembali maka perbuatan kurator tetap dianggap sah dan mengikat debitor. Kedua pasal tersebut menunjukkan bahwa sejak putusan pernyataan pailit diucapkan kurator telah berwenang untuk menjalankan tugasnya terhadap harta pailit bahkan apabila diajukan upaya hukum lain.

Akan tetapi dalam pelaksanaannya hal tersebut sulit dilaksanakan karena kurator tidak memiliki bukti kewenangannya untuk bertugas atau legalitas. Hal ini disebabkan dalam Pasal 9 Undang-Undang Nomor 37 Tahun 2004 tentang Kepailitan dan Penundaan Kewajiban Pembayaran Utang, kurator baru mendapatkan salinan putusan pernyataan pailit paling lambat setelah 3 hari sejak tanggal putusan pailit diucapkan, padahal kurator harus segera memulai melaksanakan tugas dan kewenangannya setelah pengangkatan.

Ketidakpastian dalam Undang-Undang Nomor 37 Tahun 2004 tentang Kepailitan dan Penundaan Kewajiban Pembayaran Utang tersebut diperburuk lagi dengan fakta dalam praktik bahwa tidak jarang putusan pailit baru diterima oleh kurator dalam jangka waktu lebih dari 3 hari, khususnya putusan-putusan pailit pada tingkat kasasi dan peninjauan kembali di mahkamah agung. Dapat dibayangkan bagaimana 
Nindita Widi Afreeportamara, Pujiyono. Hambatan kurator dalam menyelesaikan ...

akibat dari keterlambatan diterimanya putusan pailit oleh seorang kurator terhadap keselamatan harta pailit. Keharusan untuk memberitahukan putusan pailit kepada kurator segera pada saat putusan pailit diucapkan bukanlah suatu hal yang mustahil, karena di Belanda, negara asal referensi pelaksanaan prinsip 'zero hour principle' tersebut selalu memastikan seorang kurator yang diangkat mengetahui perihal pengangkatannya sebagai kurator pada hari yang sama saat putusan pailit tersebut diucapkan (Ricardo Simanjuntak, 2008: 39).

\section{Pengurus Koperasi}

Kurator dalam menyelesaikan pengurusan koperasi mengalami beberapa hambatan. Hambatan tersebut berupa:

a) Pengurus Koperasi Masih Menguasai Harta Koperasi

Ketika koperasi telah diputus Pailit terkadang pengurus masih menguasai harta koperasi. Sesuai dengan Pasal 91 Undang-Undang Nomor 37 Tahun 2004 tentang Kepailitan dan Penundaan Kewajiban Pembayaran Utang kurator berwenang mengamankan harta kekayaan debitor pailit dan melakukan inventarisasi harta pailit. Untuk menghindari debitor melakukan hal-hal yang tidak diinginkan maka dengan alasan untuk mengamankan harta pailit, kurator dapat meminta penyegelan harta pailit kepada hakim pengawas berdasarkan Pasal 99 ayat (1) Undang Nomor 37 Tahun 2004 tentang Kepailitan dan Penundaan Kewajiban Pembayaran Utang.

b) Pengurus Tidak Bertanggung Jawab

Apabila pengurus tidak bertanggung jawab untuk mengganti kerugian, maka bagi penuntut umum berhak untuk melakukan tuntutan pidana. Kerugian yang ditanggung pengurus tidak dibebankan kepada semua anggota pengurus untuk menanggungnya melainkan hanya kepada mereka yang melakukan kelalaian atau kesengajaan sehingga terjadi kerugian terhadap koperasi tersebut.

Bila kelalaian itu melibatkan beberapa orang pengurus, maka mereka menanggung kerugian secara bersama-sama atau tanggung renteng. Seorang pengurus dapat bebas dari tanggungannya apabila dapat membuktikan bahwa kerugian koperasi tersebut tidak disebabkan karena kelalaiannya dan telah berusaha dengan segera dan secukupnya untuk mencegah akibat dari kelalaian itu (Ika Armyta N.A, 2016: 8).

\section{Jumlah Harta}

Apabila koperasi berada dalam keadaan merugi dan tidak dapat membayar utangutangnya.Penyelesaian piutang koperasi yang diputus pailit adalah segera berakhir dengan melakukan Likuidasi. Likuidasi Koperasi dapat membantu merestrukturisasi utang-utang koperasi yang belum terbayarkan dan juga menghentikan kewajiban koperasi terhadap Negara (pembayaran pajak). Hal ini mengakibatkan koperasi tetap bertanggung jawab terhadap sisa utang dalam perkara kepailitan. Likuidasi juga dapat membantu merestrukturisasi utang-utang koperasi yang belum terbayarkan dan juga menghentikan kewajiban koperasi terhadap Negara (pembayaran pajak). Yang menjadi permasalahan Apabila koperasi berada dalam keadaan merugi dan tidak dapat membayar utang-utangnya. 


\section{Kreditor}

Hambatan-hambatan kurator dalam menyelesaikan piutang kreditor yaitu:

a) Kesulitan Menentukan Jenis Kreditor

Cara menentukan jenis kreditor yaitu dengan rapat pencocokan piutang. Pencocokan Piutang atau disebut dengan tahap sekestrasi atau tahap penyimpanan atau penitipan dimaksudkan untuk melakukan pencocokan mengenai utang Debitor atau piutang Kreditor. Pencocokan dimaksud baik mengenai kedudukan Kreditor, pengakuan sebagai Kreditor maupun mengenai besarnya piutang.

Kemudian kurator mencocokkan perhitungan piutang yang diserahkan oleh Kreditor dengan catatan yang telah dibuat sebelumnya Kemudian Hakim pengawas membacakan "Daftar Piutang Yang Diakui Sementara" dan "Daftar Tagihan Yang Dibantah" setelah itu Kurator akan memberikan keterangan-keterangan tentang status dari para Kreditor, apakah sebagai kreditor separatis, kreditor preferen ataupun kreditor konkuren.

b) Terdapat Kreditor Fiktif

Kreditor fiktif adalah kreditor yang sebenarnya tidak ada, yang merupakan kreditor yang diada-adakan untuk tujan tertentu, seperti memenuhi persyaratan permohonan pailit. Seorang kreditor dapat disebut sebagai kreditor fiktif apabila saat diminta dokumen-dokumen resmi atau sah yang berkaitan dengan kepengurusan harta pailit tidak dapat menunjukka dokumen yang diminta. Kreditor fiktif selain dimunculkan oleh kreditor, bisa juga dimunculkan oleh debitor itu sendiri sehingga harta pailit dimungkinkan akan kembali kepada si debitor.

Apabila ini terjadi maka pelaku bisa dijerat dengan pasal tentang pemalsuan yang ada pada KUH Pidana. Ketentuan-ketentuan tersebut berkaitan dengan pembuatan surat-surat yang isinya tidak mengandung kebenaran atau surat-surat yang dipalsukan sebagaimana diatur dalam Bab XII yang berjudul "Tentang Pemalsuan Surat", khususnya Pasal 263, 264, dan 266. Terdapat satu pasal KUH Pidana, yaitu Pasal 520, yang terkait dengan Penundaan Kewajiban Pembayaran Utang (Muhammad Redha Anshari, 2016:137).

Untuk mengetahui adanya kreditor fiktif pada saat pemeriksaan berkas verifikator harus jeli. Bisa juga diperiksa melalui laporan keuangan koperasi, perjanjian-perjanjian yang back date. Oleh karena itu, perlu diadakannya standar verifikasi guna memperketat kreditor-kreditor yang akan mengajukan piutangnya agar dapat dibayar oleh debitor. Tujuan standar verifikasi terhadap kreditor yaitu memperkecil hadirnya kreditur fiktif dalam kepailitan . Namun, terkadang debitor pailit juga menyalahgunakan lembaga pailit dengan menghadirkan kreditor fiktif dalam pengajuan permohonan pailit. Itikad baik dari masing-masing pihak sangat penting dalam penyelesaian masalah kepailitan.

Peran pengadilan niaga dianggap penting terhadap pencegahan hadirnya kreditor fiktif dalam permohonan kepailitan. Hal ini disebabkan Undang-Undang Kepailitan belum mengakomodir ketika adanya kreditur fiktif dalam kepailitan. Ketika Undang-Undang Kepailitan belum mengaturnya, sudah sepatutnya Pengadilan 
Nindita Widi Afreeportamara, Pujiyono. Hambatan kurator dalam menyelesaikan ...

Niaga melakukan pencegahan hadirnya kreditor fiktif yang dapat merugikan berbagai pihak. (Isdian Anggraeny, 2018:8).

\section{Ketersediaan Dana}

Penyelesaian suatu kepailitan membutuhkan dana yang tidak sedikit, begitu kurator menerima putusan pernyataan pailit dari Pengadilan Niaga dalam waktu yang relatif pendek harus mempersiapkan dana untuk pengumuman ikhtisar putusanpernyataan pailit dan batas akhir pengajuan tagihan kreditor/penyelenggaraan rapat pencocokan piutang. Pengumuman sebagaimana diatur dalam Pasal 15 ayat (4) dan Pasal 114 tersebut memerlukan dana lebih dari Rp.10.000.000,- (sepuluh juta rupiah) dan dalam anggaran rutin tidak ada posnya.

\section{Simpulan}

Kurator saat menyelesaikan piutang koperasi yang diputus pailit mengalami hambatanhambatan yaitu dalam hal Regulasi berupa kurangnya perlindungan hukum terhadap Kurator dan Undang-undang Nomor 37 Tahun 2004 tidak jelas mengatur kapan legalitas diberikan kepada kurator untuk melaksanakan tugasnya. Pengurus Koperasi masih menguasai harta koperasi dan adanya Pengurus yang tidak bertanggung jawab. Dalam hal jumlah harta yaitu apabila Koperasi dalam keadaan merugi dan tidak dapat membayar utang-utangnya. Kurator juga kesulitan menentukan Kreditor dan terdapat Kreditor Fiktif dan terakhir mengenai ketersediaan dana karena penyelesaian suatu Koperasi yang diputus membutuhkan dana yang tidak sedikit

\section{E. Saran}

Untuk mengatasi hambatan-hambatan yang dihadapi oleh kurator dalam menyelesaikan piutang koperasi yang diputus pailit dalam hal setelah putusan pailit kurator segera mengamankan harta koperasi hal ini guna menghindari kemungkinan pengurus mengalihkan harta koperasi dan apabila terdapat Pengurus koperasi yang tidak bertanggung jawab dapat dipidana dengan memakai pasal pidana penggelapan yaitu Pasal 374 Kitab Undang-Undang Hukum Pidana. C. Apabila Koperasi dalam keadaan merugi dan tidak dapat membayar utang-utangnya. Jalan yang dapat ditempuh untuk menyelesaikan masalah tersebut, yaitu dilakukannya pelelangan dan pemberesan berupa pembagian/pelunasan kepada para kreditor atas harta koperasi dan jika hasil pelelangan ternyata masih didapati kekurangan untuk mencukupi pelunasan maka hal inilah yang di dalam hukum perdata masuk kedalam kategori naturlijke verbintennis yaitu sebagai sisa hutang orang yang pailit dimana pihak kreditor tidak memiliki hak lagi untuk pelunasannya .

\section{F. Daftar Pustaka}

G.Ida Bagus Adi Wiradharma. 2018. "Perlindungan Hukum Terhadap Kurator dalam Melaksanakan Tugas Pengurusan dan Pemberesan Harta Debitor Pailit”. Jurnal Kertha Semaya .Volume 6 Nomor 4. Bali: Fakultas Hukum Udayana. 
Ika Armyta N.A dkk. 2016. “Tanggung Jawab Pengurus Koperasi Terhadap Pembubaran Koperasi di Indonesia Ditinjau dari Undang-Undang Nomor 25 Tahun 1992”. Diponegoro Law Journal. Volume 5 Nomor 3 . Semarang: Fakultas Hukum Universitas Diponegoro.

Imran Nating. 2004. Peranan dan Tanggung jawab Kurator Dalam Pengurusan dan Pemberesan Harta Pailit. Jakarta: PT. Raja Grafindo Persada.

Isdian Anggraeny. 2018. "Peran Pengadilan Niaga Akibat Adanya Kreditur Fiktif Dalam Kepailitan”. Yurispruden. Volume 1 Nomor 2. Malang: Fakultas Hukum Universitas Islam Malang.

Muhammad Redha Anshari. 2016. "Rekayasa Piutang oleh Kreditor untuk Memenuhi Persyaratan Permohonan Pernyataan Pailit”. Lex Renaissance. Volume 1 Nomor 1. Yogyakarta: Fakultas Hukum Universitas Islam Indonesia.

Peter Mahmud Marzuki. 2014. Penelitian Hukum. Jakarta: Prenadamedia Group.

Ricardo Simanjuntak. 2008. "Ketentuan Hukum Internasional dari UU Nomor 4 Tahun 1998 (Cross Border Bankruptcy)". Jurnal Hukum Bisnis. Volume 27 Nomor 1. Jakarta: Fakultas Hukum Universitas Atmajaya.

Kitab Undang-Undang Hukum Perdata

Kitab Undang-Undang Hukum Pidana 